\title{
Stability Analysis of a Hybrid Power Plant: An Analysis through ETAP Software
}

\author{
Md. Shazzadul Islam and Muhammad Fayyaz Khan
}

\begin{abstract}
Transient analysis plays an important role in power system. Transient analysis is aimed at determining whether a system will remain in synchronism with other generating plants after disturbances. In this paper, transient stability for a small power plant (80MW) coupled with a small solar plant has been studied through ETAP software. The plant is operating as IPP

(Independent Power Producer) and owned by United Power Generation \& Distribution Co. Itd. (UPGD) under United Group, Bangladesh. Effect of fault on generating plant and solar plant side has been studied. In this paper our main aim is to show the effect of any type of fault on the power plant side is very low when fault occurs at solar plant side. The plant almost remains unhindered due to fault in the solar part of the proposed hybrid plant. Complete analysis has been done under ETAP software environment to predict the stability of the hybrid plant. As Bangladesh government is taking up a project to install MW range solar PV based plant that will be hooked up with the national grid, the present study will give an idea as to predict the behavior of the hybrid system especially as far as the stability of the overall system is concerned.
\end{abstract}

Index Terms-ETAP, transient stability analysis, solar system, disturbance, system stability, inertia constant.

\section{INTRODUCTION}

Synchronous generators respond to fast changes in electromechanical swings and during these swings generators get into a situation when the rotor angle stabilizes at a new value or the rotor angle will gradually increase which may take the system to a loss of synchronism [1]. The vital aim of transient stability is to determine whether the system returns to a steady state value after the clearance of disturbance [2]. Normally without solar plant the effect of fault at any point of the plant is high. The proposed method is developed based on the swing equation and the theory of control system. The well-known classical swing equation which is related to synchronous generator rotor swing angle is [3],

$$
M \frac{d^{2} \delta}{d t^{2}}=P_{a}=P_{m}-P_{e}
$$

where,

Manuscript received December 30, 2018; revised March 1, 2019. This work was supported by the research and development project 'Efficient design for biodynamic lighting to promote the circadian rhythm in offices buildings' (ref BIA2017-86997-R), as well as the TEP-130 Research group.

Shazzadul Islam is with the Department of Electrical and Electronic Engineering, Global University Bangladesh (GUB), Barisal, Bangladesh (e-mail: shazzadulislam89@gmail.com).

Mohammad Fayyaz Khan is a Pro Vice Chancellor, Green University of Bangladesh

$$
M=\frac{2 H}{\omega_{S}},
$$

$P_{a}$ is the accelerating power,

$P_{m}$ is the mechanical power,

$P e$ is the electrical power output,

$\omega_{s}$ is the synchronous angular velocity of the rotor, $\delta$ is the synchronous machine rotor angle,

$H$ is the inertia constant.

The power output of the single machine connected to anInfinite bus at any instant of time is,

$$
P_{e}=P_{m x m} \sin \delta
$$

The mechanical power input equal to the pre fault electrical power output at an initial angle $\delta_{0}$ is given as,

$$
P_{m}=P_{m x m} \sin \delta_{0}
$$

System reactance is different during occurrence of fault from the reactance after the clearing the fault.

A number of PV panels connected in series and in parallel giving a DC output for the incident of irradiance. Hybrid systems can address limitations in terms of fuel flexibility, the major types of hybrid power system are, Grid Connected Hybrid Systems, Isolated Grid Hybrid Systems.

\section{LAYOUT OF THE POWER Plant}

For the stability analysis, as already mentioned a small plant of $80 \mathrm{MW}$ has been considered with twelve generators running in parallel. The plant is named as DEPZ plant located at EPZ area SAVAR, Dhaka. The plant has 12 generators (combination of Wartsilla \& Rolls Royce generators) connected to two separate buses known as WARTSILA(DW) and Rolls Royce(RR) bus respectively. Four generators are connected to WARTSILA bus each is rated as $8.73 \mathrm{MW}$ and five generators connected to Rolls Royce bus each rated as 9.34MW. There are three small Generators known as MTU connected to WARTSILA bus.

TABLE I: SPECIFICATIONS FOR WARTSILA GENERATORS

\begin{tabular}{|l|l|}
\hline Output & $8.73 \mathrm{MW}$ \\
\hline voltage & $11 / 11000 \mathrm{~V}$ \\
\hline current & $573 \mathrm{~A}$ \\
\hline speed & $750 \mathrm{rpm}$ \\
\hline Over speed & $900 \mathrm{rpm}$ \\
\hline Weight & $27000 \mathrm{~kg}$ \\
\hline Inertia & $2150 \mathrm{kgm}^{2}$ \\
\hline p.f & .80 \\
\hline Number of gen & 4 \\
\hline
\end{tabular}


TABLE II: SPECIFICATIONS FOR ROLLS ROYCE

\begin{tabular}{|l|l|}
\hline Output & $9.34 \mathrm{MW}$ \\
\hline Current & $638 \mathrm{~A}$ \\
\hline Weight & $34500 \mathrm{~kg}$ \\
\hline
\end{tabular}

\begin{tabular}{|l|l|}
\hline Speed & $750 \mathrm{rpm}$ \\
\hline Number of gen & 5 \\
\hline
\end{tabular}

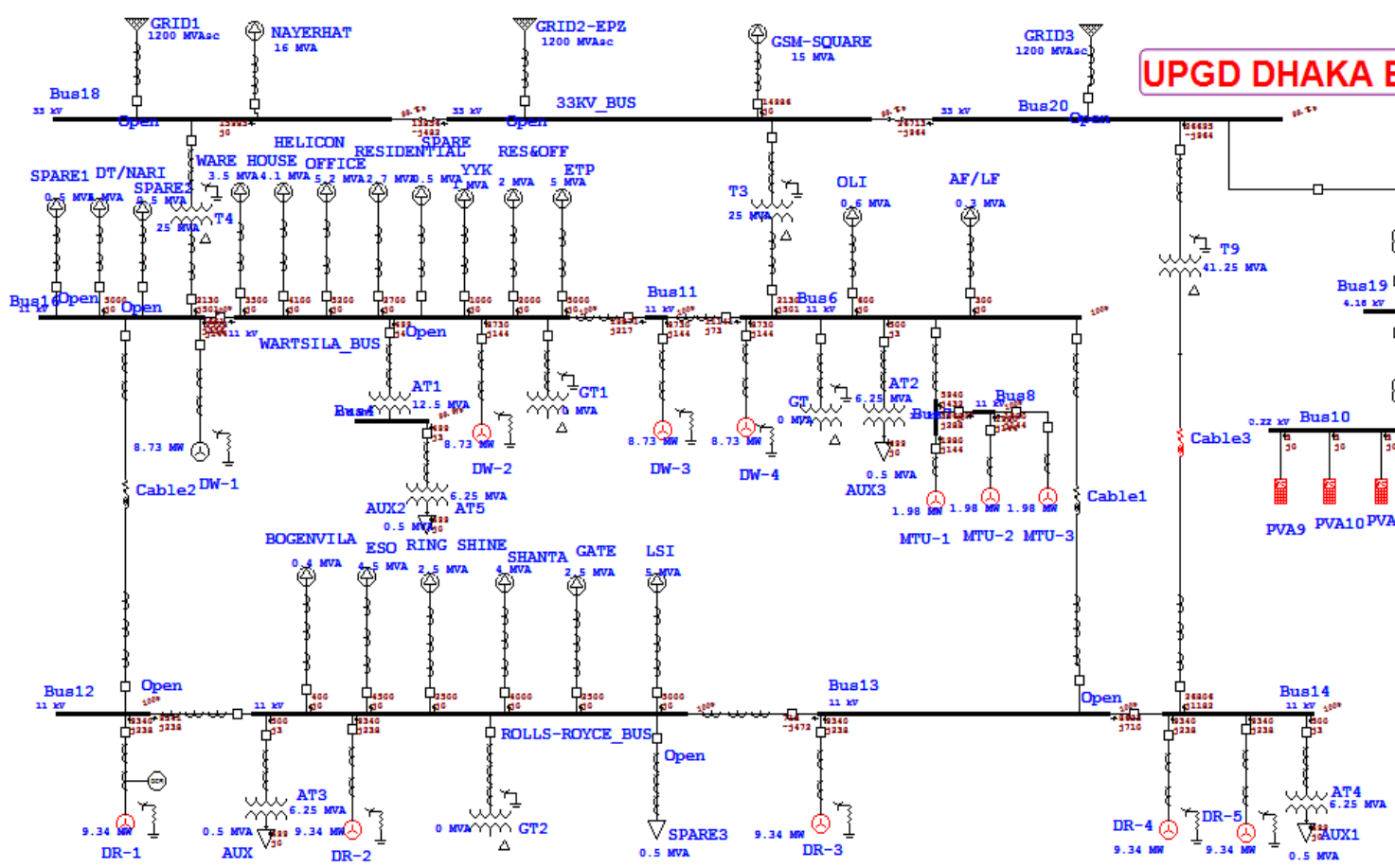

Fig. 1. Sin line diagram and load flow analysis of the system.

TABLE III: SPECIFICATION OF SOLAR PLANT

\begin{tabular}{|l|l|}
\hline Watt/Panel & 214.5 \\
\hline Series Panel/Array & 4 \\
\hline Parallel Panel/Array & 4 \\
\hline Total Panel/Array & 16 \\
\hline Fill Factor & $78.11 \%$ \\
\hline efficiency & $14 \%$ \\
\hline Total KW & 20 \\
\hline
\end{tabular}

\section{TRANSIENT ANALYSIS OF THE SYSTEM}

Transient stability the ability of a power system to maintain synchronism under large disturbance conditions like severe three phase faults, line switching etc. We can thus define the power system stability as the ability of the power system to return to steady state without losing synchronism. The general main problem of a power plant is to maintain stability at the time of large disturbances. When situation is critical, that time generators of this power plant are disconnected from the system one by one, they can no longer run with the system. This situation arises as inertia of all the generators are very low. Our main objective is to create symmetrical fault in different sensitive points of the plant and visualize the impact of fault on stability. Stability analysis has been done under different conditions like when the plant is operating under grid mode or islanding mode.

Grid mode operation:

a. Fault on $11 \mathrm{kv}$ Rolls-Royce bus

b. Fault on solar plant

Island mode operation

c. Fault on $11 \mathrm{kv}$ bus and solar plant side.

In island mode operation effect of fault is same if fault occur anywhere of the plant. That's why we consider only $11 \mathrm{kv}$ bus. During simulation there are two interconnector namely ic1 and ic2 kept open and close simultaneously.

\section{DESIGN OF PROPOSED SOLAR PV Plant}

UPGDCL's Power Plant inside Dhaka Export Processing Zone is situated over an area of 6,125.13 sq. meters. Inside the power plant has some free space, so company take a decision to make a hybrid power plant. The main concern of this paper is analysis stability of the DEPZ power plant if we add a solar plant in the existing power plant. The longitude and latitude of the land are $23.70 \mathrm{~N} \& 90.40$ E Respectively. As the land is predominately made up of hard soil. Also during monsoon season the land is not inundated by water, so there is no problem in rainy season. The amount of power that can be generated from PV panels installed on the land for an approximate area of 0.5 acres.

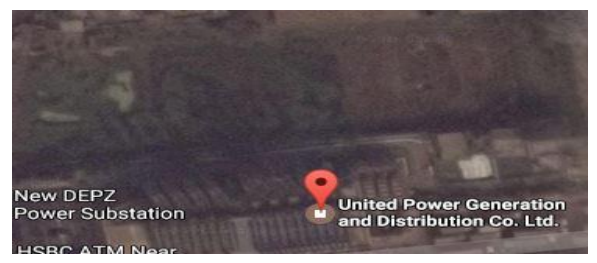

Fig. 2. Proposed land near the DEPZ power plant.

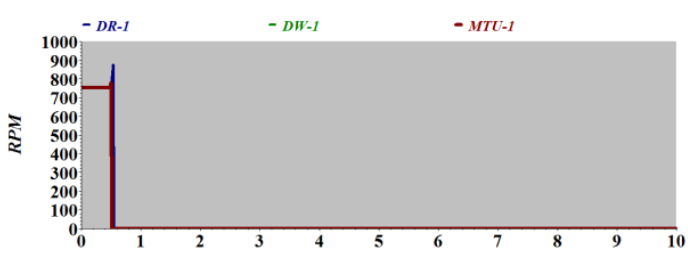

Fig. 3. Speed of wartsila rolls-royce and Mtu. 


\section{RESULTS AND DISCUSSION}

Case1:

At first fault crated on $11 \mathrm{KV}$ RR bus and two interconnector kept close then analyze the stability of the system. Fault occurs at $.5 \mathrm{~s}$ and cleared at $.6 \mathrm{~s}$ clearing time of fault is .1s.this is shown in Fig. 3 to Fig. 7.

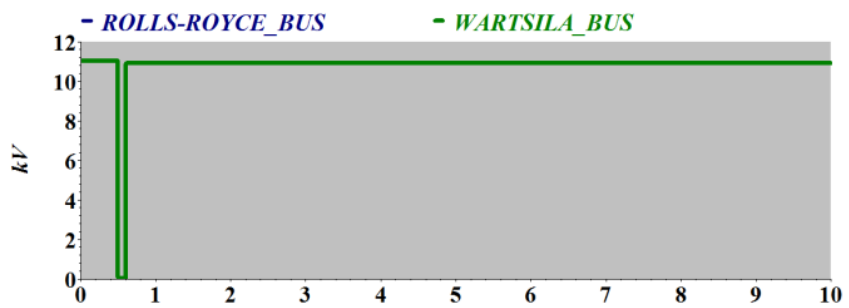

Fig. 4. Bus voltage of RR and Wartsila.

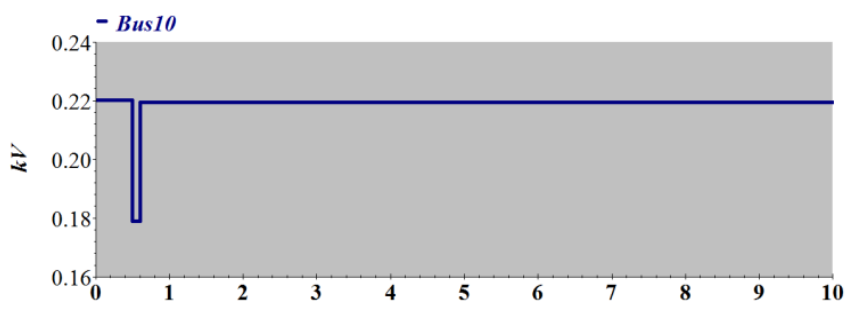

Fig. 5. Bus voltage solar plant.

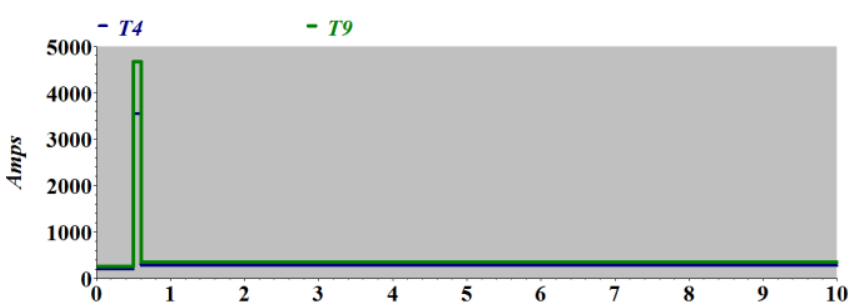

Fig. 6. Terminal current of RR, DW, MTU

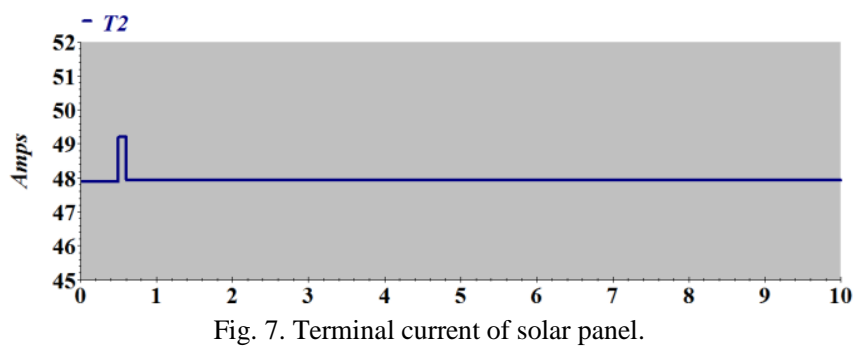

From Fig. 3 it can be seen that all generators disconnected from the system due to high amount of short circuit current.

TABLE IV: DATA AT FAULT ON RR BUS (IC1\&IC2 CLOSED)
\begin{tabular}{|l|l|l|l|l|l|l|}
\hline \multirow{2}{*}{$\begin{array}{l}\text { Bus } \\
\text { Name }\end{array}$} & \multicolumn{2}{|l|}{ Pre fault } & \multicolumn{2}{l}{ During fault } & \multicolumn{2}{l|}{ Post fault } \\
\cline { 2 - 7 } & (A) & $(\mathrm{KV})$ & $(\mathrm{A})$ & $(\mathrm{KV})$ & $(\mathrm{A})$ & $(\mathrm{KV})$ \\
\hline RR & 343 & 11 & 4800 & 0 & 343 & 11 \\
\hline DW & 246 & 11 & 3600 & 0 & 246 & 11 \\
\hline $\begin{array}{l}\text { Solar } \\
\text { bus }\end{array}$ & 48 & .22 & 49 & .18 & 48 & .22 \\
\hline
\end{tabular}

In gas power plant side effect is much higher than solar plant, because ic1 and ic2 is closed and solar plant is connected to the grid. In case 2 analyzed the effect of fault when ic1 and ic2 is opened.

Case2:

Again fault is created on $11 \mathrm{KV}$ RR bus (ic1\&ic2 open) then analyzed stability of the both plants.
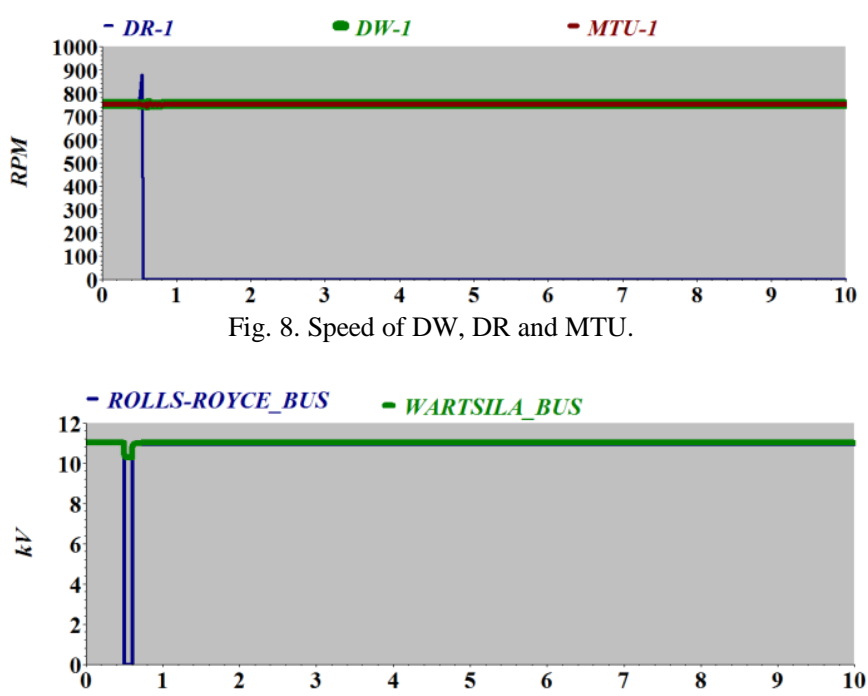

Fig. 9. Bus voltage of DR and DW.
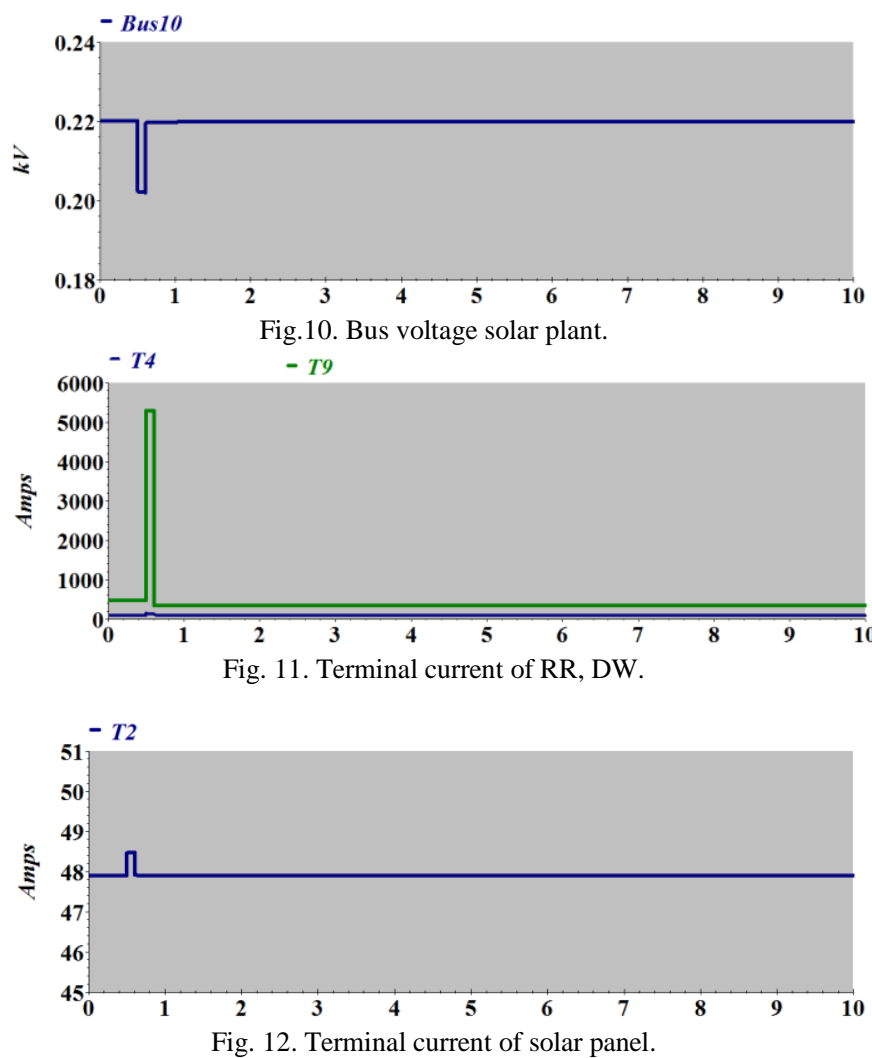

TABLE V: DATA AT FAULT ON RR BUS (IC1\&IC2 OPEN)

\begin{tabular}{|l|l|l|l|l|l|l|}
\hline \multirow{2}{*}{$\begin{array}{l}\text { Bus } \\
\text { Name }\end{array}$} & \multicolumn{2}{|l|}{ Pre fault } & \multicolumn{2}{l|}{ During fault } & \multicolumn{2}{l|}{ Post fault } \\
\cline { 2 - 7 } & $(\mathrm{A})$ & $(\mathrm{KV})$ & $(\mathrm{A})$ & $(\mathrm{KV})$ & $(\mathrm{A})$ & $(\mathrm{KV})$ \\
\hline RR & 490 & 11 & 5380 & 0 & 490 & 11 \\
\hline DW & 275 & 11 & 460 & 0 & 275 & 11 \\
\hline $\begin{array}{l}\text { Solar } \\
\text { bus }\end{array}$ & 48 & .22 & 48.5 & .20 & 48 & .22 \\
\hline
\end{tabular}

From figure8 only faulty bus generators disconnected from the system. So it can be seen that when ic1 \& ic 2 is open then effect of fault reduces the whole system except faulty bus. In solar plant bus fault current further decreases.

Case 3:

Fault created on solar plant bus, fault occurs at $0.5 \mathrm{~s}$ and cleared at 0.6 s clearing time of fault is 0.1 s.results shown in below. 


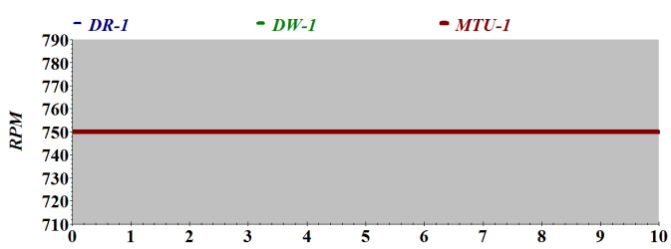

Fig. 13. Speed of DW, DR and MTU.
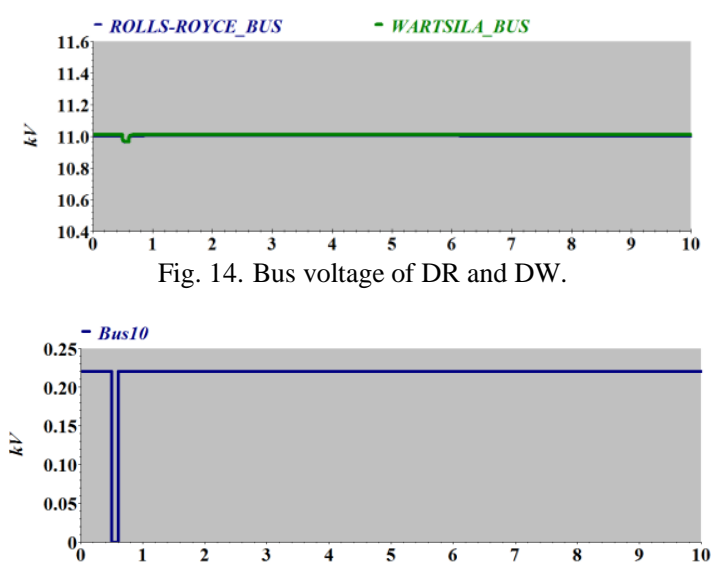

Fig. 15. Bus voltage solar plant.

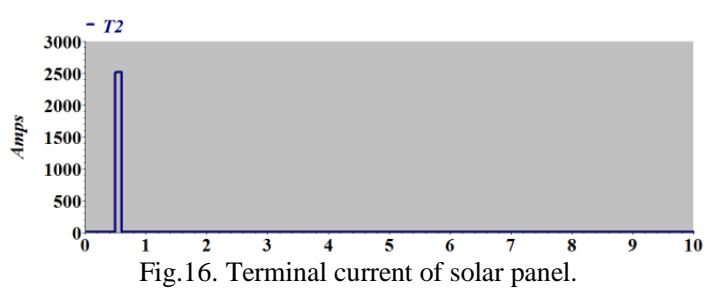

Fig. 13 shows that no generators lose synchronism from the system because effect is very less in generator side. Fig. 15 and Fig. 16 shows that the fault voltage and current of solar plant side.

\section{Case4:}

Now the system operates in Islanding mode, this mode is very peculiar. This mode fault occurs in anywhere of plant effect is same. That's why fault created on $11 \mathrm{KV}$ Rolls-Royce bus.
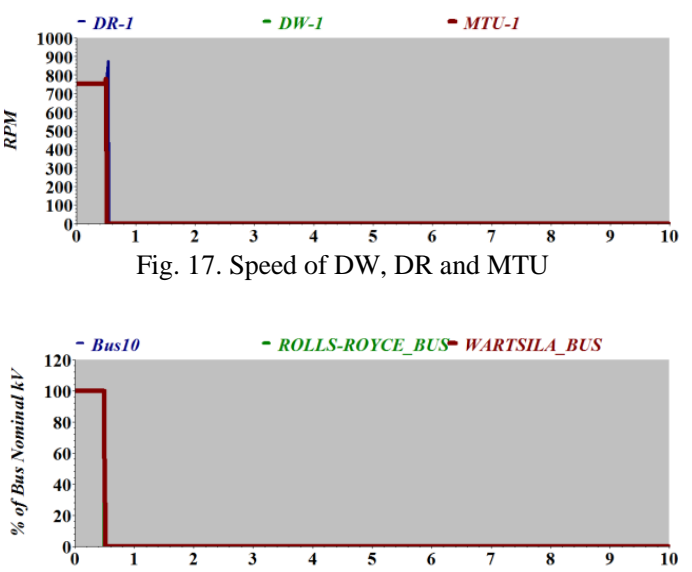

Fig.18. Bus voltage of DR, DW and solar plant.

Fig. 17 shows that every generator disconnected from system they can no longer stay with the system. Every bus voltage goes to zero when fault occurs but when fault is cleared the system voltage not recovered.

\section{CONCLUSION}

A hybrid power system consists solar PV and gas engine generators .The existing power plant was gas engine based. The whole analysis completed by ETAP software environment. The simulation and analysis have been applied in different fault location. Complete study outcome is shortened as the renewable generation unit less negative impact on the stability of the system except islanding mode operation. The critical clearing time is studied for this analysis.

\section{REFERENCES}

[1] D. Reváková, Ž. Eleschová, and A. Beláň, "Prechodné javy v elektrizačných sústavách,” Bratislava, Vydavatel'stvo STU, 2008.

[2] S. K. Nallagalva, M. K. Kirar, and G. Agnihotri, "Transient stability analysis of the IEEE 9-Bus electric power system," International Journal of Scientific Engineering and Technology, vol. no.1, no. 3, pp. 161-166, July 2012

[3] Hadisadat, "Power system analysis," McGraw-hill international editions, power systemanalysis," McGraw-Hill International Editions, 1999.

[4] Vision of Solar Power Development through Asia Solar Energy Initiative (ASEI), Renewable-Energy, Power Division, Ministry of Power, Energy and Mineral Resources, Government of Bangladesh.

[5] D. Chatterjee and A. Ghosh, "Transient stability assessment of power systems containing series and shunt compensators," IEEE transactions on Power Systems, vol. 22, no. 3, 2007.

[6] P. Kundur, "Power system stability and control," EPRI Power System Engineering Series, Newyork, Mc-Graw-Hill Inc,1994.

[7] M. A. Salam, "Fundamentals of power systems," Alpha Science International Ltd, Oxford, 2009, pp. 336-358.

[8] R. C. Dugan, M. F. McGranaghan, S. Santoso, and H. W. Beaty, "Electrical power systems quality 2nd Edition," Professional Engineering, McGraw-Hill pp 383-392.

[9] R. K. Jaganathan and T. K. Saha, "Voltage stability analysis of grid connected embedded generators," in Proc. Australasian Universities Power Engineering Conference (AUPEC 2004) Brisbane Australia.

[10] J. S. Patel and M. N. Sinha, "Power system transient stability analysis using ETAP software".

[11] R. A. J. Khan, M. Junaid, and M. M. Asgher, "Analysis and monitoring of 132 grid using ETAP software".

[12] Siemense and IRENA, "Renewable energy in hybrid mini-grids and isolated grids: economic benefits and business cases," UNEP Collaborating Centre, Germany.

[13] M. S. Aziz1, U. Saleem, E. Ali, and K. Siddiq, "A review on bi-source, off-grid hybrid powergeneration systems based on alternative energy sources," Journal of Renewable and Sustainable Energy, vol. 7, 2015.

[14] S. K. Nallagalva, M. K. Kirar, and G. Agnihotri, "Transient stability analysis of the IEEE 9-bus electric power system," IJSET, vol. 1, no. 3 , pp. 161-166.

[15] Transient Stability. Available: [Online] http://www.kau.edu.sa/Files/0056868/Subjects/Chapter\%20pdf

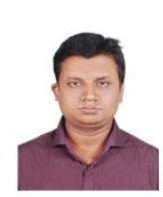

Shazzadul Islam was born in Noakhali, Bangladesh

$\mathrm{He}$ received his bachelor degree in electrical and electronic engineering from United International University (UIU), Dhaka, Bangladesh. He is a lecturer at Department of Electrical and Electronic Engineering, Global University Bangladesh (GUB), Barisal, Bangladesh. His researches interests include are smart grid, solar energy, and power system.

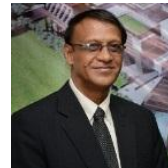

Mohammad Fayyaz Khan was born in Chittagong, Bangladesh. He is a Pro Vice Chancellor, Green University of Bangladesh. Former Faculty of University of Bahrain, IUT and Former Professor and Head of EEE/CSE Department of AUST, UAP, UIU respectively.

His research interests include: Renewable Energy, Control Systems, Drives, and Energy Conversions. 